at the University of Warsaw, it has a scientific council presided over by Professor Kazimierz Majewski, Member of the Polish Academy of Sciences. The Centre has a staff of eight permanent research workers and auxiliary scientific and technical workers, whose work is focused on socio-cultural transformations of Black Africa, the Arab countries of Africa, and problems pertaining to the South African Republic. Of particular interest are the problems of transition from tribal to national systems and the rise of national culture, the relations between races and religions, pan-African tendencies, and the activities of the Organization of African Unity.

The Centre publishes collections of studies by its workers in special issues of Przeglad Socjologiczny (The Sociological Review) of which the first appeared in 1965 (volume 19, part 1 ), the second in 1967 (volume 21 , part $r$ ) and a third is in the press.

\title{
Eighth West African Languages Congress
}

THE Eighth West African Languages Congress was held at the University of Abidjan under the chairmanship of Professor J. Greenberg from 24 to $28 \mathrm{March}$ 1969. There were over eighty participants and some fifty papers were presented for discussion in general session and in sectional working parties on Oral Literature (Chairman, Professor Robert Armstrong), Lexicography (Chairman, Dr. Pathé Diagne), and on Benue-Congo Languages (Chairman, Professor Vorhoeve). The Benue-Congo working party continued the discussions initiated on this subject at the Sixth Congress held at Yaounde in March I 966 and considered a report on a special meeting held at Leiden in September 1968. A report of the Congress, including the papers submitted and the discussions and resolutions, is being prepared under the editorship of Professor M. Houis, for publication by the University of Abidjan for the West African Linguistics Society.

The next meeting of the Congress will be held in March/April $197^{\circ}$ at Fourah Bay College, Freetown, under the chairmanship of Professor Houis. Further information concerning the Congress and the West African Linguistics Society can be obtained from the Hon. Secretary, Professor Ayo Bamgbose, Department of Linguistics and Nigerian Languages, University of Ibadan, Nigeria.

\section{Colloque sur les classes d'âge en Afrique de l'ouest}

UN colloque sur ' Les classes d'âge en Afrique de l'ouest' s'est tenu à Paris, du I9 au 2 I mai I 969 , dans le cadre du Centre d'études africaines de l'E.P.H.E., Vle section, et du Groupe de recherches en anthropologie et sociologie politiques (Sorbonne). Présidence de Mme D. Paulme. La discussion s'est appuyée sur les communications suivantes: P. Charest: 'Les classes d'âge chez les Malinké animistes de Kedougou (Sénégal oriental)'. J. Capron: 'Les classes d'âge chez les Bwa (Haute Volta)'. P. Mercier: 'Les classes d'âge en milieu somba (Dahomey) '. P. Wassungu: ' Classes d'âge et initiation chez les Nawdeba (Togo)'. G. Le Moal: 'Les classes d'âge chez les Bobo (Haute Volta)'. M. Gessain: 'Les classes d'âge chez les Bassari d'Etyolo (Sénégal oriental)'. D. Paulme: ' Les classes d'âge dans le sud-est de la Côte d'Ivoire'. J. Hurault: 'Les classes d'âge dans le système social de Bamiléké (Cameroun)'. H. Raulin: 'Sociétés sans classes d'âge au Niger. M. Bekombo: 'Les classes d'âge chez les Duala (Cameroun)'. Un volume collectif publiera les contributions à ce colloque. Une bibliographie analytique du sujet le complétera, préparée par les soins du CARDAN.

\section{State University of New York, African Studies Faculty Committee: First Annual Conference at New Paltz}

The African Studies Faculty Committee of the State University of New York held its first annual conference at the Ashokan campus of the State University College at New Paltz, 
New York, on I I-I 2 April 1969, bringing together State University faculties from various campuses and representatives of several New York State school districts.

Dr. Joseph E. Harris, Professor of African History at New Paltz, opened the conference with an introductory address. The themes of the several sessions of the two-day meeting included 'African studies in schools, colleges, and universities' and ' Racial prejudice, teaching, and learning: Africans and Afro-Americans'. Speakers included Professor Edward Soja, Northwestern University, Dr. Frances Bonner, Psychoanalyst, of Newton, Massachusetts, and Mr. Ray Giles, of the African-American Institute.

\section{Symposium on the African Cultural Contribution in Latin America and the Carib- bean Area}

Tris symposium was held in Havana from 17 to 21 December 1968, organized by UNESCO, the Cuban National Commission for UNESCO, and the Institute of Ethnology and Folklore of the Cuban Academy of Sciences. Some twenty specialists attended from Latin America, Europe, and Africa, among them Miguel Acosta-Saignes (Venezuela), Aguirre Beltrán (Mexico), Ildefonso Pereda-Valdés (Uruguay), Léon G. Damas (Guyana), Roger Bastide (France), José A. Portuondo, Director of the Cuban Institute of Literature and Linguistics, and Argeliers Léon, Director of the Cuban Institute of Ethnology and Folklore. Papers were delivered in the fields of cultural anthropology, musicology, literature, and history of thought. The principal subjects of the conference were related to the adaptation of the Afro-Latin-American to the Western cultures, the transmission of Afro-American culture and the creation of a new culture.

\section{(Communicated by Luis Beltrán)}

\section{The Institute for the Study of Man in Africa}

THE Institute's seventh annual Raymond Dart Lecture was delivered by Professor Monica Wilson of the University of Cape Town on 4 June 1969. The subject was 'The thousand years before Van Riebeeck : reflections on early peoples of South Africa'.

\section{La Participation des facultés et instituts europeéns au développement juridique africain}

L'Association internationale de Droit africain (International African Law Association) a tenu à Bruxelles, du 2 au 5 juillet 1969 , une réunion consacrée à la participation des facultés et instituts européens au développement juridique africain. Une trentaine de participants y représentaient des facultés ou instituts de recherche allemands, américains, anglais, belges, français, italiens et scandinaves, en même temps que des institutions internationales comme l'Institut international pour l'Unification du Droit privé (UNIDROIT); chacun d'entre eux avait présenté dans une brève note les réalisations et les projets de son institution dans le domaine du droit africain. Les discussions, présidées successivement par MM. les Professeurs Wengler (Berlin), Young (Northwestern), Costanzo (Pérouse), Allott (Londres) et Rubbens (Leuven) permirent, au cours des deux premières journées, d'examiner à la fois le bilan de l'oeuvre accomplie et les problèmes que posait l'avenir tant de la recherche que de l'enseignement du droit africain dans les facultés et instituts d'Europe. A cette occasion, l'accent fut fréquemment mis sur la nécessité d'une coordination des efforts européens. Aussi la dernière journée fut-elle consacrée à la mise en oeuvre de cette coopération européenne au service de l'Afrique. La conférence décida notamment de mettre en chantier la création d'un Centre européen de droit africain qui aurait notamment pour tâches de dresser un répertoire permanent des enseignants et chercheurs travaillant dans ce domaine scientifique, d'établir des contacts entre ceux-ci et les universités et gouvernements africains, 